\title{
Article
}

\section{Investigation of Screen Printed Micro-Electrodes and Paste Rheology}

\author{
Noriyuki SAKAI ${ }^{* * * * *}$, Takatsune NARUMI ${ }^{* *}$, Ryutaro TAKAHASHI ${ }^{* * *}$, and Akiomi USHIDA ${ }^{* *}$ \\ *Graduate School of Science and Technology, Niigata University \\ ${ }^{* *}$ Institute of Science and Technology, (Faculty of Engineering), Niigata University \\ 8050 2-no-cho Ikarashi, Nishi-ward, Niigata 950-2181, Japan \\ ${ }^{* * *}$ Technical R\&D Division, Namics Corp. \\ 3993 Nigorikawa, Kita-ku, Niigata 950-3131, Japan
}

\begin{abstract}
This study examines the relationship between paste properties and screen-printing phenomena. Since the printing includes multiple processes those are generated almost simultaneously, it is necessary to investigate respective processes. In this report, we have focused transfer printing processes from the screen to a substrate. We have tested model silver pastes with different surface treatment to the silver particles. Several kinds of rheological properties of test pastes were measured and results of model printing experiments and real fine line electrode printings were correlated to the properties. It was found that the shear stress characteristics in the bulk form did not directly relate to printing performance and the other factors, such as oil absorption volume which affected flowability of the paste surface, must be further important. The study also confirmed that the tendency in oil absorption volume agreed with the conventional size electrode printing performance. But, paste residual phenomena was generated in the case of ultrafine line printing with $30 \mu \mathrm{m}$ width and printing performance was influenced with other factors because of very narrow gap generated with a mesh and open area in the screen.
\end{abstract}

Key Words: Screen-printing / Paste rheology / Oil absorption volume / Electrode / Ultrafine line printing

\section{スクリーン印刷による微細電極形成とペーストレオロジー特性} 坂井 徳幸 ${ }^{* * * *,}$, 鳴海 敬倫 ${ }^{* *}$, 高橋 竜太郎 ${ }^{* * *}$, 牛田 晃臣**

（原稿受理：2017 年 4 月 29 日）

\section{1. 緒 言}

導電性ペーストのスクリーン印刷はエレクトロニクス分野 で電子回路などの電極を製造する技術として幅広く利用され ている. ${ }^{1,2)}$ 太陽電池の表面電極形成 ${ }^{3,4)}$ もその中の一つであり, 近年, 太陽電池特性の向上するために，表面電極の細線化と 高アスペクト化が望まれている。細線化はシャドーロスを低 減し受光面積を増加するためであるが, 単に細線化してしま うと電極の断面積が低下してしまい電極のライン抵抗が増加 する。そこで，高アスペクト化し電極厚みを増すことができ れば, 電極断面積の低下を抑止し, 良好な電極性能を発現す

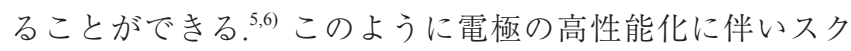
リーン印刷にも高精度な技術が要求されている。 しかしなが ら，スクリーン印刷による電極形成に関する研究は少なく, 未解明な点も多い. それは, スクリーン印刷のときのペース 卜の挙動を直接観察することが困難であることと, 数多くの

\footnotetext{
$\dagger$ Tel : +81-25-258-5577, Fax : +81-25-258-5511, E-mail : nsakai@namics.co.jp

* 新潟大学大学院自然科学研究科

T950-2181 新潟市西区五十嵐 2 の町 8050

** 新潟大学自然科学系 (工学部)

テ950-2181 新潟市西区五十嵐 2 の町 8050

***ナミックス株式会社

厂950-3131 新潟市北区濁川 3993
}

工程が瞬時に行われるためにおのおのの工程に切り分けて解 析することが難しいことが一因にある.7) そのため, これまで は主に回転粘度計によりバルク状態で測定された粘度物性 ${ }^{8,9}$ と印刷後に乾燥を加えられた電極形状との関係が検討され報 告されてきた。しかし, 回転粘度計の物性と乾燥後の電極形 状観察のみでは, スクリーン印刷の複雑で多くの工程をぺー ストがどのように流動しているのか確認できず，印刷技術の 向上のためには不十分であった。したがって，工程を分けて 個々の影響を明らかにすることが必要である.

スクリーン印刷の模式図を Fig. 1 に示す。一般的に, スク リーン印刷では, メッシュで補強され，開口部を有する乳剂 で形成されたスクリーンの上にペーストをコーティングし, その後、ゴム製のスキージがスクリーンを電極基板に押しつ けながら，スクリーン上を移動することにより，転写・印刷 する。このスクリーン印刷工程はペーストのレオロジーとせ ん断速度変化の観点から 5 つの工程に分けることができる.

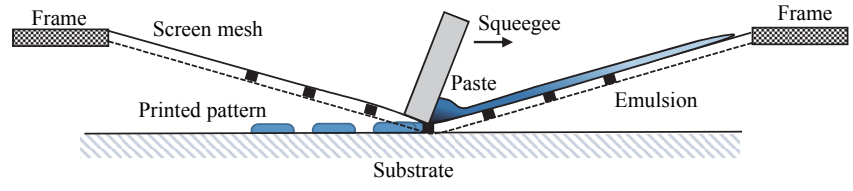

Fig. 1 Schema of screen printing. 
すなわち，印刷前にペーストがスクリーン上で静止している 状態（I），印刷が開始されスクリーン面上のスキージ前で ペーストがローリングする状態（II ), スクリーン開口部に ペーストが充填される工程（III）, スクリーンマスクの版離 れ工程 (IV), そしてペーストのレベリング状態 $(\mathrm{V})$ であ る. ${ }^{10)}$ 静止状態 (I ) は, 弱い降伏特性を有するペーストが 静置している状態である。次のローリング状態（II）では, スキージがペーストを回転流動させながらスクリーンマスク 上を移動し，その際，数 $10 \mathrm{~s}^{-1}$ 程度のせん断流れ場となると 言われている。 そして最もせん断速度が変化するのは（III） と（IV）の工程である。すなわち，スクリーン開口部に充填 される工程 (III) では, 数十 $\mu \mathrm{m}$ 幅の開口部に瞬時に流入す るため, 約 $1000 \mathrm{~s}^{-1}$ という高いせん断速度の流れ場となると 言われている. ${ }^{10)}$ 版離れ（IV) とは，スキージで基板に押し つけられたスクリーンマスクがそのテンションにより基板か ら離れる工程である。 スクリーン開口部に充填されたペース トが基板に転写され，版離れする際にはメッシュや開口部の 溝側壁面およびメッシュと基板との間で引っ張りを受けるた め, 伸長も重要な流れ場となり, 変形速度も急減に低下する, 最後はレベリング工程 $(\mathrm{V})$ であるがペーストが応力から解 放され，せん断速度は $0.1 \mathrm{~s}^{-1}$ 以下という流れ場となる。

本研究では, この 5 つの工程の中で変形速度が最も激しく 変化し, 細線化を目指す場合に印刷結果に大きく影響すると 予想される版離れ工程 (IV) に注目して検討した. 多くの要 因が影響する複雑な変形を伴うペーストの流動特性を把握す るには, 真球のモデル粒子を使うなど, 材料も簡単化するの も一つの手法であるが, 結果的に本来の印刷結果と対応しな い可能性がある。そこで, 本研究では実際に印刷する材料 (銀粒子) を用いて, 現実的に可能な改善案として, 銀粒子 の表面処理を変えたことによる流動時の物性への影響と実際 の印刷結果との対応を検討する手法を用いる。このため, た だちに理論的観点からの解明を目指すのではなく, 工業レオ ロジーとしての知見を提供することにより，この分野の発展 に寄与することを主な研究目的とする. 具体的には, いくつ かの観点からペーストのレオロジー的特性を検討し, 版離れ 工程についてモデル化した流れ場の実験との対応を検討する. さらに, この材料を用いて実際に超細線印刷を行い, 従来と 異なる観点でのペーストの物性と印刷現象との対応を考察す る.

\section{2. 供試流体とそのレオロジー物性}

\section{1 供試流体}

実験には，表面処理の異なる銀粒子を分散させた 3 種類の ペーストを用いた。すなわち, 表面処理を行っていない銀粒 子 $(\mathrm{N})$ と, 表面処理剂である不飽和脂肪酸 (U), 複素環式 芳香族化合物（H）をそれぞれ表面にコートした試料の 3 種 類である。すべての銀粉の平均粒子径は $1.5 \mu \mathrm{m}$ である。こ れらの銀粒子とガラス粉末を溶剂であるブチルカルビトール， ブチルカルビトールアセテート, 樹脂などの固形有機物であ る不飽和脂肪酸，エチルセルロース，フェノール樹脂に加え， 金属三本ロールで均一になるように分散した。すべてのペー ス卜の体積分率は銀粉 46.4\%, ガラス粉 $2.2 \%$, 溶剂 $36.6 \%$, 固形有機物 $14.8 \%$ とした。分散媒がニュートン流体である ことは確認している.

\section{2 バルク状態のせん断変形特性}

最初に，実験に供したペーストのバルク状態の粘度特性を， せん断速度範囲を分けて, 三つの粘度計を用いて測定した。 まず, スクリーンマスク充填と版離れ工程のせん断速度域で ある 10〜 $1000 \mathrm{~s}^{-1}$ の範囲の粘度を Malvern 社製 ROSAND RH2200 キャピラリーレオメータを使用し, ダイの穴径 $0.5 \mathrm{~mm}$ で測定した。 また，ローリング工程のせん断速度域 である $0.4 \sim 40 \mathrm{~s}^{-1}$ の範囲の粘度を Brookfield 社製粘度計 HBT，スピンドル SC4-14 で測定した。さらに，レベリング 工程のせん断速度域である $0.001 \sim 1 \mathrm{~s}^{-1}$ の範囲の粘度を Thermo Scientific 社製レオメータ HAAKE MARS IIIで，測定 端子 直径 $35 \mathrm{~mm}, 2^{\circ}$ のコーンプレートを用いて測定した。

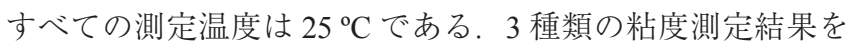
Fig. 2 に重ねて示す。それぞれの粘度計で測定範囲の上下限 では, 測定誤差や不安定性の発生のため, なめらかに連続し たデータラインにはならないが, 各せん断速度領域での相対 的な違いは確認できる。 まず，低せん断速度域ではペースト による粘度の違いがみられ，未処理粒子を用いたペースト $\mathrm{N}$ が最も粘度が低く，H，Uの順に粘度が高くなっている．粒 子径, 体積分率などを統一しているのに粘度が変わる点は, 粒子の凝集性に影響したと予想される，後に示すように，表 面処理剂は塗れ性を改善したことになるが，かえって凝集性 を上げたものと考えられる。しかし，この影響は，高せん断 速度になるにつれて薄れ，ペース卜間の粘度差は縮まる傾向 にある。例えばせん断速度が $1000 \mathrm{~s}^{-1}$ 近傍では, ペースト間 の粘度差はほとんどなくなっている.

続いて，上述のレオメータ HAAKE MARS III 用い，同 じ測定端子で動的粘弾性および降伏特性を測定した。動的粘 弾性測定では，プレシアの状態によりデータが異なるなど流 動履歴の影響が現れることが確認されたため, 試料とコーン のセッティング以上の変形を加えない状態で周波数を $1(\mathrm{~Hz})$ で固定し, 応力振幅を変化させる応力振幅掃引測定を行った. 線形（微小変形）領域では, ほぼ一定の $G^{\prime}, G^{\prime \prime}$ が得られた

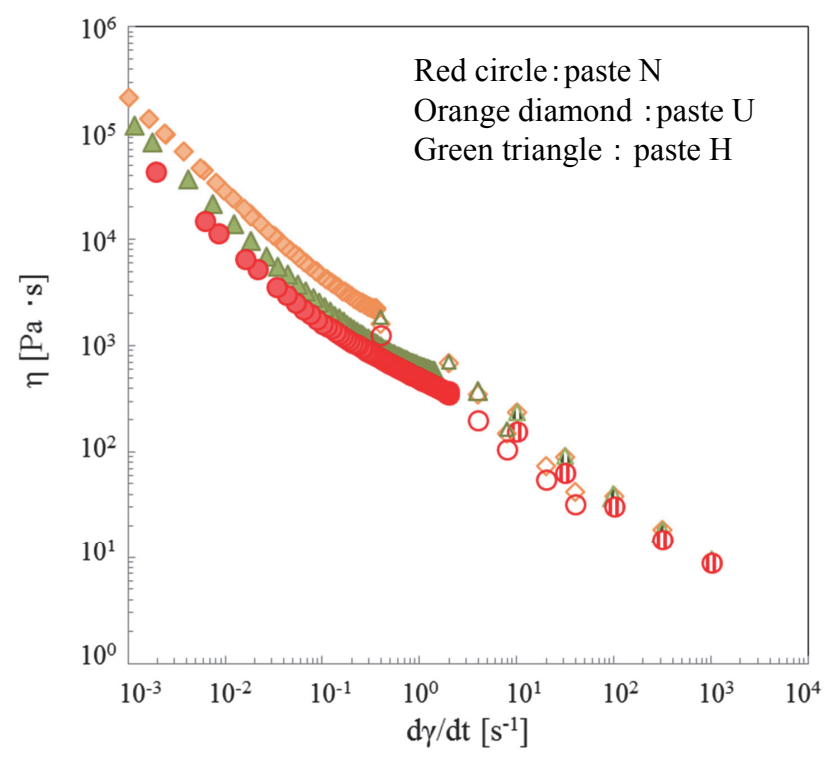

Fig. 2 Shear viscosity $\eta$ of test fluids measured at $25 \mathrm{C}$. Closed makers means data measured by HAAKE MARS III, opened makers means data measured by Brookfield HBT viscometer and stripe makers means data obtained with ROSAND RH2200. 
ので，その值を用いて試料間の定性的な比較を行う。Table I に $G^{\prime}, G^{\prime \prime}$ の值を示す。周波数が低いこともあり，低せん断 速度域の粘度特性同様にペースト $\mathrm{N}$ が $G^{\prime}, G^{\prime \prime}$ ともに最も低 い值を示し, ペースト $\mathrm{H}, \mathrm{U}$ の順に高い值を示している。こ れは, 上述の凝集性の違いが, 剛性率にも同様に現れたと考 えられる。 なお, 高周波域の測定はサンプルの不安定性など が生じ，困難であった。

さらに，せん断下における降伏応力を特徴付けるために応 力掃引測定を行なった. 同じジオメトリーで, 応力を $10 \mathrm{~Pa} / \mathrm{s}$ の割合で増加させ, せん断速度の変化を調べた。明確な降伏 現象を示さないが, 高せん断速度域側からの外挿值として, 降伏応力を算定した結果を同じ Table I に示す. 相対的な大 小関係は粘度等の傾向と一致し, ペースト $\mathrm{N}$ が最も低い. しかし, いずれも高々数 $100 \mathrm{~Pa}$ と十分に低く, 版離れ工程 への影響は少ないと思われる.

\section{3 曳糸性}

先に述べたように，版離れ工程では伸長特性も重要と考え られる。しかし，本実験で扱う濃厚分散系ではフィラメント を形成し難く，一般的な伸長粘度計では測定が難しい。実際， HAAKE 社製 CaBER1 伸張粘度計による測定を試みたが，有 意な結果は得られなかった。そこで，同機を応用し理論的な 值は得られないが, 伸長変形のし易さを曳糸性として比較し た. CaBER1 伸張粘度計の引き離し運動を利用して, ペース トが伸張されて, 切れるまでの時間をハイスピードカメラで 観察し, 測定した。引き上げスピードを $30 \mathrm{~mm} / \mathrm{s}$ とし, ペー ストを上下のプレートは直径 $1 \mathrm{~mm}$, 初期ギャップ $1 \mathrm{~mm}$, 終了ギャップ $16 \mathrm{~mm}$ でその間を $0.5 \mathrm{~s}$ で移動させた。測定温 度は $25^{\circ} \mathrm{C}$ とした。破断までの時間を測定した結果を Fig. 3

Table I Linear viscoelastic properties of test fluids measured with a rheometer at small amplitude oscillatory shear mode $(1 \mathrm{~Hz}) . G^{\prime}$ elastic modulus, $G^{\prime \prime}$ loss modulus and $\tau$ yield stress.

\begin{tabular}{cccc}
\hline Silver paste & $\mathrm{N}$ & $\mathrm{U}$ & $\mathrm{H}$ \\
\hline$G^{\prime}(\mathrm{Pa})$ & $1 \times 10^{5}$ & $3 \times 10^{6}$ & $3 \times 10^{5}$ \\
\hline$G^{\prime \prime}(\mathrm{Pa})$ & $4 \times 10^{4}$ & $2 \times 10^{5}$ & $1 \times 10^{5}$ \\
\hline$\tau(\mathrm{Pa})$ & 200 & 300 & 390 \\
\hline
\end{tabular}

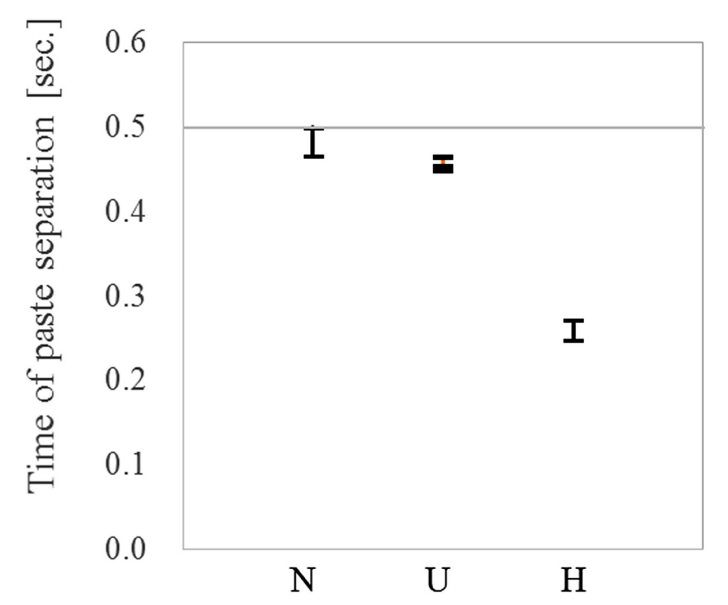

Fig. 3 Times of paste separation measured in elongating processes of CaBER1.
に示す。 5 回の測定で得られた結果の範囲を示している. ペースト $\mathrm{N}$ は $0.5 \mathrm{~s}$ 付近の值を示すが, これは終了ギャップ に達してもペーストが切れないものもあったことを意味する. 一方で, ペースト Uも変形性が高い結果が得られており, ペースト H が最も早く切れる結果となった，Uと Hの関係 は，低せん断速度域のせん断粘度とは逆の傾向を示す。 H が Elongational thickening 特性を有する可能性もあるが, この現 象は自由表面を有する変形であり，表面での変形性の違いが 影響している可能性も高いも考えられる。 そこで, 表面流動 について次に検討し, その後, この現象について再度考察す る.

\section{4 吸油性と表面流動}

版離れ工程では，表面を有する変形となる，表面が存在す る場合のペーストの流動性の指標を検討するために, 二つの 実験を行った。最初に銀粉の吸油量を調査した。吸油量の測 定方法は日本工業規格 JIS K-5101-13-2 にあり，粉体に徐々 に油を滴下し，混練していったとき，流動性を与えるために 要する油量である。この值そのものは，レオロジー物性では ないが，粉体としてのぬれ性を検討する目安になると考えら れる。なお，一般的に吸油量測定はDOP（ジイソオクチル フタレート）を用いるが，本実験ではペーストに使用した溶 剂を用いた。

測定方法は，銀粒子に溶剤を少量ずつ添加し，スパチュラ を用いてアルミ板上でよく混合し練った。練ったスラリーが らせん状になるまで溶剤を加え, その溶剤量を調べ, 式 （1）により吸油量を求めた。

$$
\mathrm{OA}=\mathrm{V}_{\mathrm{s}} / \mathrm{W}_{\mathrm{a}} \times 100
$$

ここで, OA : Oil absorption $(\mathrm{ml} / 100 \mathrm{~g}), \mathrm{V}_{\mathrm{s}}$ : Volume of solvent (ml), $\mathrm{W}_{\mathrm{a}}$ : Weight of silver (gram) である. 測定した吸油量を Fig. 4 に示す. 吸油量は, 本研究の供試流体の溶剤量を基準 にすると，2つグループに分けることができた。すなわち， 印刷に使用する供試ペーストの溶剂含有量は, 組成比の銀粉 $46.4 \mathrm{vol} \%$, 溶剂 $36.6 \mathrm{vol} \%$ とそれらの比重から換算すると銀

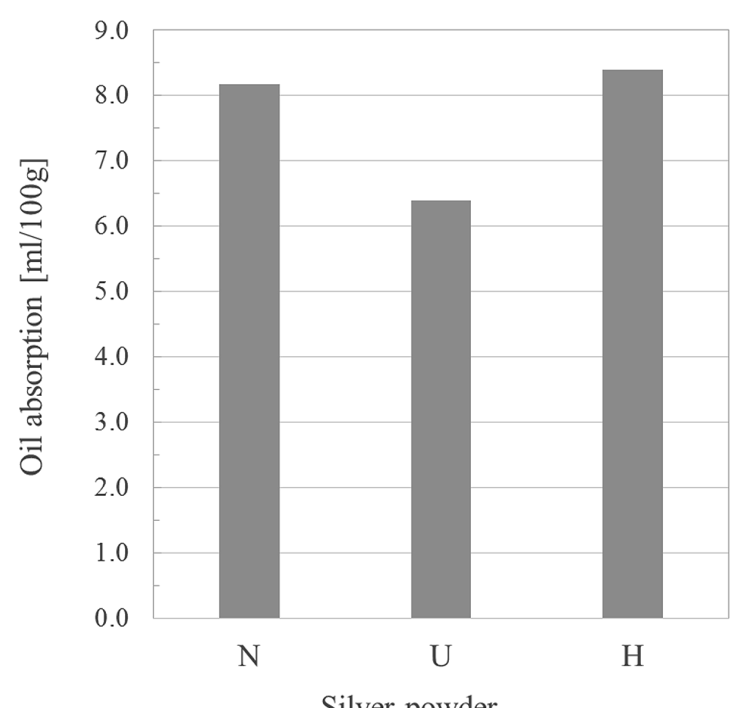

Fig. 4 Oil absorption of silver powders tested to the carrier liquid. 
粉末 $100 \mathrm{~g}$ に対して $7.5 \mathrm{ml}$ であり, これに比較して吸油量が $7.5 \mathrm{ml}$ 以下の銀粉 $\mathrm{U}$ と, 吸油量 $7.5 \mathrm{ml}$ 以上の $\mathrm{H}$ と $\mathrm{N}$ である. どの試料も溶剤量は同じであるが, ペーストUは吸油量よ り多くの溶剤が含まれており, 銀粒子群がすべて液体中に 浸っており粒子が気体と接することがない浸漬状態にある。 銀粒子表面上に十分な溶剂が存在するため固体-液体状態を 保ち流動でき，粉体のぬれ性が関わる流れでは，流動性が高 く, 変形しやすいと予想される。一方, ペースト Hと N の 溶剤量は吸油量より少なくペンジュラー状態11)であり銀粒 子間に液体と気体が混在する状態である。つまりペースト中 に不均一領域を含んでおり, その固体一固体部分が流動を阻 害し，変形しにくいと考えられる。

この流動現象を確かめるため, 各銀粉に樹脂を加えず溶剤 のみ $7.5 \mathrm{ml}$ を加え混練し，そのスラリーを作製した。シリ コン基板に厚み $45 \mu \mathrm{m}$ のセロハンテープを $0.5 \mathrm{~mm}$ の間隔を あけて 2 枚平行に貼り溝を作った。溝の端にスラリーを乗せ, ブレードで溝に広がるように伸ばし塗膜を形成した。セロ八 ンテープを剥がした後, $150{ }^{\circ} \mathrm{C} て ゙$ 乾燥した塗膜表面を顕微鏡 にて観察した。その結果の代表例を Fig. 5 に示す。銀粉末 U は平滑な塗膜となり， $\mathrm{H}$ と $\mathrm{N}$ は表面に凹凸のある塗膜と なった。この凹凸はブレードで伸ばす時点で発生しており, 薄膜形成時に均一な流動が生じにくいことを示す。特に自由 表面を形成する流れであり, 流動不安定性は自由表面近傍の 粒子の挙動に起因すると予想される. 吸油量の違いに現れた ように，粒子表面のぬれ性が悪いと予想される $\mathrm{H}$ と $\mathrm{N}$ では， 気相を巻き込みやすく, 流動性が不均一となり, このような 凹凸が生じたものと考えられる，ところで，H は表面処理さ れており，一般的な意味ではぬれ性は上がっているはずであ る. 本実験で用いている銀粒子は真球ではなく, 表面に微細 な凸凹があり，予想されるマクロな現象でのぬれ性の向上と は, 異なる現象が現れている可能性がある。このミクロな凹 凸面への表面処理の効果については, 現時点では明確な知見 はなく, より詳細な検討が必要と考えられる。本実験では, 本節で得られた結果を, 表面流動性の良好の根拠として扱う こととする。すなわち, 吸油量が小さく均一に分散されてい るペーストUは, 表面を含む流れでは, 流動性が良好にな ることが確認された

ここで, 2.3 節の現象をこの結果も踏まえて, 再度考察す る. 本研究で行った曳糸性の実験には, バルクの流動性の影 響と表面の流動性の影響の両方が現れていると考えられる. $\mathrm{H}$ が最も曳糸性が低い点は表面の流動性が影響したと考えら れ，Uとの違いは両者のバルクの流動性が同程度とすれば, 表面流動性の良好な Uとの違いとして説明つけられる。し かし，Nは表面流動性が悪いにもかかわらず，U と同程度の 曳糸性を示している。 この点は, Nのバルクの流動性の高さ

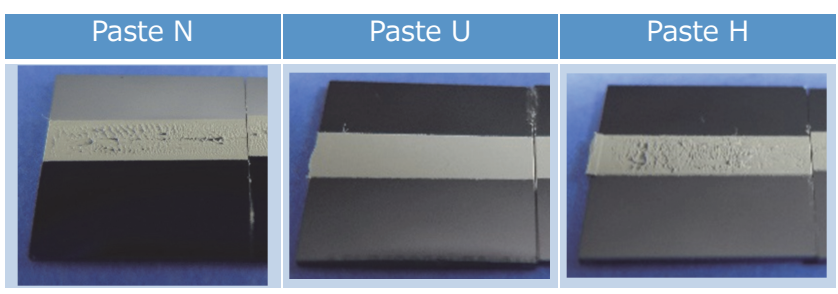

Fig. 5 Surfaces of coated layers observed by microscope after drying at 150 C. Rough surfaces are obtained with Pastes $\mathrm{N}$ and $\mathrm{H}$ and Paste $\mathrm{U}$ shows smooth surface.
が現れたと予想される。しかし，バルクと表面の流動性の両 者の影響が線形的な足し算として現れているのではなく，複 雑に影響し合っていると予想され, 正確な考察にはより詳細 な研究が必要と考えられる。本研究で対象としているスク リーン印刷では, 同様の伸長流動が現れるが, 流動現象のサ イズはより小さい場合であり, バルクよりも表面流動の影響 が強くでる可能性がある。これらの点を踏まえて, 次にスク リーン印刷での現象の検討を行う.

\section{3. 版離れモデル実験}

\section{1 擬似版離れ観察装置と観察方法}

次に版離れ工程における各ペーストの流動特性を比較する ために，擬似版離れ装置を作製し，基板と孔壁面との間に生 じる伸張変形を観察した。 厚さ $100 \mu \mathrm{m}$ のステンレス板にマ イクロドリルで直径 $\mathrm{D}=222 \mu \mathrm{m}$ の孔を開け，スクリーンを 模したステンシルとして用いた。 なお，剛直なステンシルを 用いたため, ペーストの抜け性を考慮し，孔は径の大きい円 形とした．Fig. 6 に実験装置の模式図を示す，孔を開けた板 状のステンシルを固定台にボルトで設置し， L 字金具に Fig. 6 のように貼り付けられたシリコン基板を下からステン シルに押し当てた。 その状態でペーストを孔に充填し，その 後, 自動 Z ステージを用いて L 字金具を下げ，ステンシル と基板を引き離すことにより版離れの挙動を再現した。引き 離し速度は，実際の版離れ工程から概算した值に近い 1.0 ,

$2.5 \mathrm{~mm} / \mathrm{s}$ で行なった. 上部からの光をプリズムでステンシル と平行に照射し，それによるペーストの影を，ミラーを介し てハイスピードカメラで撮影した。ペーストがステンシルか ら離れていく過程を観察し，そしてペーストが完全に離れた ときのペーストの形状を評価した.

\section{2 版離れモデル実験で得られた電極形状}

引き離し後の代表的な電極形状を Fig. 7 に示す。 上段は引 き離し速度 $1.0 \mathrm{~mm} / \mathrm{sec}$. 下段は引き離し速度 $2.5 \mathrm{~mm} / \mathrm{sec}$. の結 果である。孔抜け観察は各ペースト 3 回行い, 形成される形

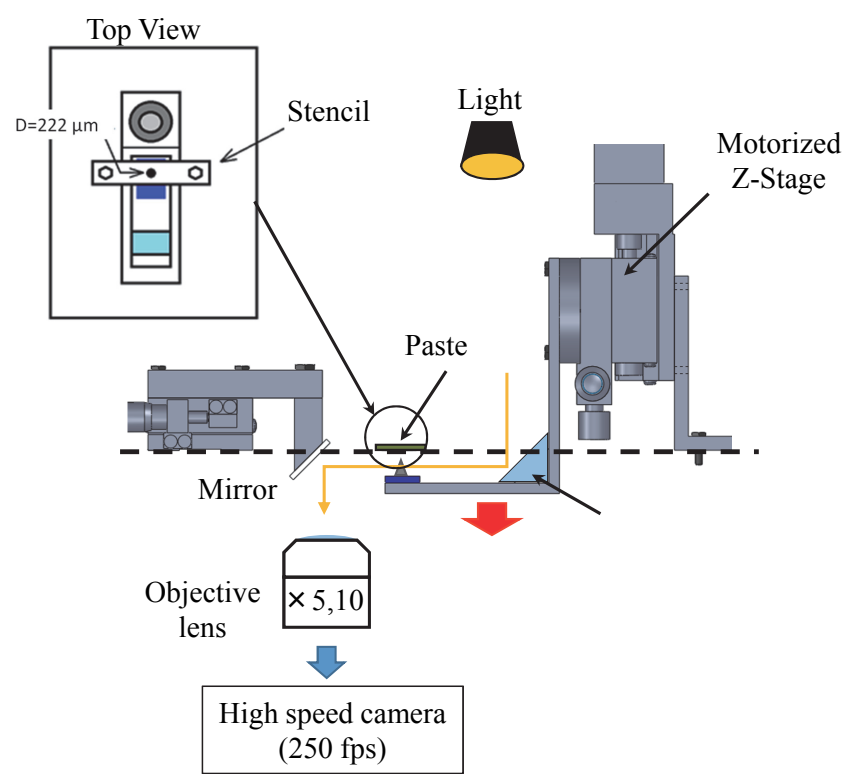

Fig. 6 Schema of experimental apparatus for model tests in separating processes. 


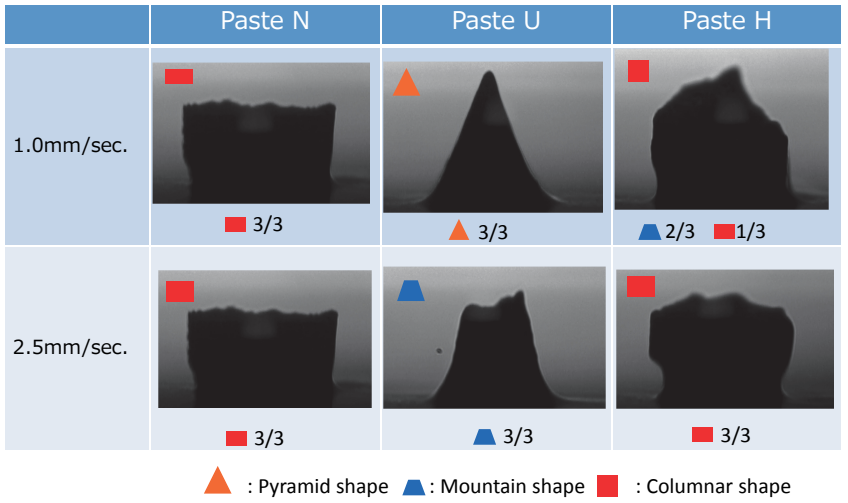

Fig. 7 Typical shapes of pastes transferred from a stencil observed by inverted microscope in the model tests.

状は打㧍むね 3 つに分類され，円錐型，山型，円柱型となっ た。電極形状と出現回数を図中に示した。 引き離し速度 $1.0 \mathrm{~mm} / \mathrm{sec}$. ではペースト U が円錐型，H と N が円柱型と なった．引き離し速度を $2.5 \mathrm{~mm} / \mathrm{sec}$.にすると引き離し速度 $1.0 \mathrm{~mm} / \mathrm{sec}$. に比べ全体的に変形しにくい形状となり, ペー ストUは山型となった。なお，ここでは省略するが，Dが 異なる条件なども検討し, この傾向の再現性は確認している.

比較的変形しやすい円錐型掞よび山型と, 変形しにくい円 柱型になる現象についてペーストの流動をミクロ的なスケー ルで捉えて考察すると, 次のように推測される. 円錐型の ペーストは銀粒子がペースト内で均一に分散され固体-液体 の流動が継続するためにペーストが引き伸ばされる. 円柱型 の場合は, 引き伸ばされていく過程の早い段階で銀粒子同士 の固体一固体接触の不均一領域が生じるために流動ができな くなり変形できなくなる。引き下げ速度を速くした場合は, 銀粒子とビヒクルが均一状態を保ちながら流動しようとする よりも，引き下げ速度の方が速いために均一性を維持できな くなり変形しにくくなる。これらの結果は, 2.2 のバルクの
粘度などの流動性の傾向とは一致せず，2.4で述べた表面を 有する場合の流動性に対応していることがわかる。すなわち， ペーストUは銀粒子表面上に十分な溶剤が存在するため表 面であっても固体-液体状態を保ち流動できるため円錐型や 山型になった。一方, ペースト $\mathrm{H}$ と $\mathrm{N}$ は表面に不均一領域 が発生しやすく，それが流動を阻害し伸長変形できず円柱型 となると考えられる.

\section{4. 実際の印刷結果}

\section{1 電極幅 $50 \mu \mathrm{m}$ のスクリーン印刷実験}

まず一般的に形成されている電極幅より，やや狭い開口幅 を持つスクリーンを用いて，それぞれのペーストの印刷特性 を確認した，マイクロテック社製の印刷機 MT550-TVを使 用し, スクリーンマスクは 290 メッシュ, 乳剤厚さ $25 \mu \mathrm{m}$, メッシュの線径 $20 \mu \mathrm{m}$ を用いた。印刷する基板はテクス チャーのある太陽電池用シリコン基板であり，設計ライン幅 $50 \mu \mathrm{m}$ のスクリーンマスクを使用し，スキージ速度 $100 \mathrm{~mm} /$ sec. で3 種類の銀ペーストを印刷した。 なお， $50 \mu \mathrm{m}$ は現行

Table II Electrode shapes obtained real screen printing processes with $50 \mu \mathrm{m}$ designed width.

\begin{tabular}{|c|c|c|c|c|}
\hline \multicolumn{2}{|c|}{ Silver paste } & $\mathrm{N}$ & $\mathrm{U}$ & $\mathrm{H}$ \\
\hline \multicolumn{2}{|c|}{ Electrode width $\mathrm{W}(\mu \mathrm{m})$} & 83.8 & 58.7 & 55.9 \\
\hline \multirow{3}{*}{$\begin{array}{l}\text { Electrode } \\
\text { thickness } \\
\quad(\mu \mathrm{m})\end{array}$} & maximum $\mathrm{H}_{\max }$ & 21.7 & 25.3 & 24.3 \\
\hline & minimum $\mathrm{H}_{\min }$ & 10.5 & 19.0 & 16.4 \\
\hline & average $\mathrm{H}_{\text {ave }}$ & 16.7 & 22.0 & 20.4 \\
\hline \multicolumn{2}{|c|}{$\begin{array}{l}\text { Standard deviation of } \\
\text { electrode thickness (-) }\end{array}$} & 2.3 & 1.6 & 2.0 \\
\hline \multicolumn{2}{|c|}{ Aspect ratio $\left[\mathrm{H}_{\mathrm{ave}} / \mathrm{W}\right](-)$} & 0.20 & 0.38 & 0.36 \\
\hline \multirow{2}{*}{$\begin{array}{l}\text { Surface } \\
\text { roughness }\end{array}$} & $\mathrm{R}_{\mathrm{a}}(\mu \mathrm{m})$ & 1.4 & 1.1 & 1.4 \\
\hline & $\mathrm{R}_{\mathrm{z}}(\mu \mathrm{m})$ & 7.7 & 5.9 & 7.1 \\
\hline
\end{tabular}

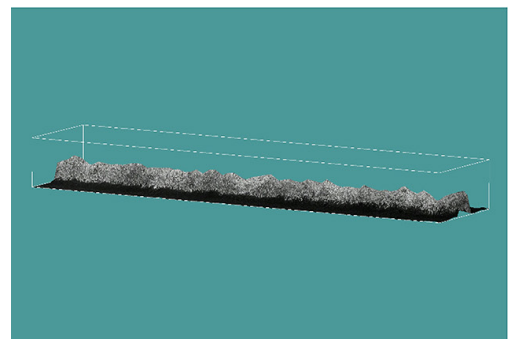

(A)

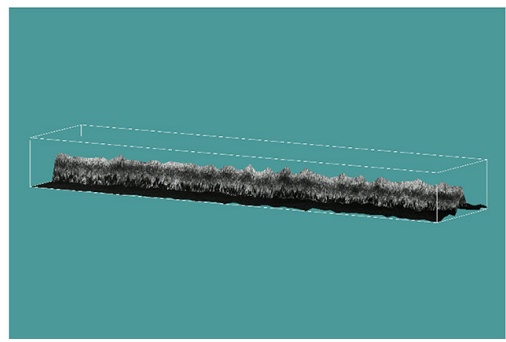

(B)

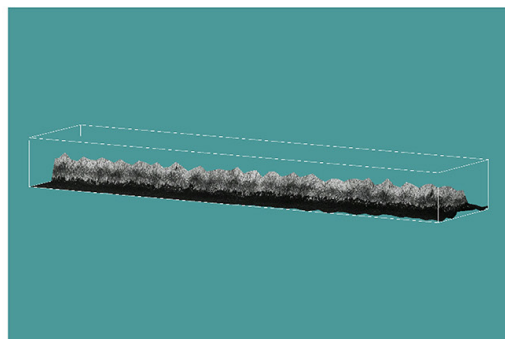

(C)

Fig. 8 Electrode shapes observed by confocal microscope obtained in real screen printing processes with $50 \mu \mathrm{m}$ designed width. (A) paste N, (B) paste U and (C) paste $\mathrm{H}$.

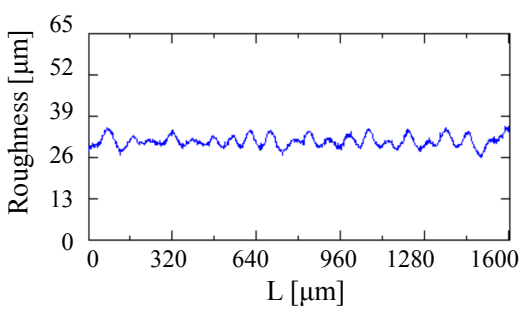

(A)

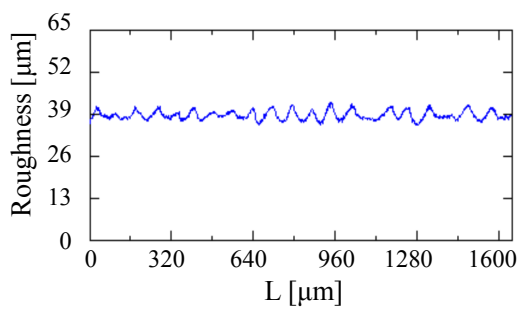

(B)

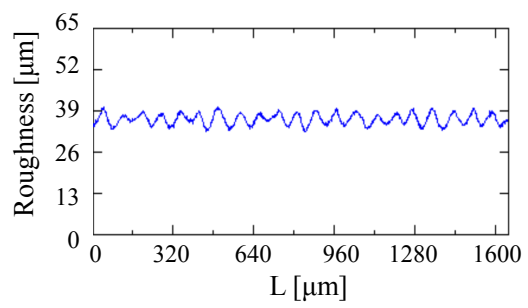

(C)

Fig. 9 Surface roughness of electrodes printed using $50 \mu \mathrm{m}$ designed width. (A) paste N, (B) paste U and (C) paste H. 
の電極では狭い方である。その後， $150{ }^{\circ} \mathrm{C} に て 1$ 分間乾燥さ せた. 乾燥後にコンフォーカル顕微鏡を用いて電極の高さ最 大, 最小, 平均值を測定した。電極幅は, 画像を二值化処理 して求めた電極面積と既知の電極長を用いて, 電極幅 $=$ 電 極面積/電極長さの計算式より算出した。 アスペクト比は電 極幅と電極高さの平均值から算出した。 電極形状と外観形状 の代表例を Table II および Fig. 8 に示す. その電極の表面粗 さの測定結果を Fig. 9 に示す。ペースト U が電極の平均高 さが最も高く, また標準偏差が小さく, 電極表面が平滑であ り,さらにアスペクト比も高く，良好な電極形状を形成する ことが分かった。

この結果は, 3.2 のモデル実験の結果と対応すると言って よい. すなわち, 表面を有する流れ場でも流動性の高い, U が実際の版離れ時でも良好な転写性を示すと考えられる。こ の結果からも, バルクでのせん断粘度などの検討だけでは, 印刷性に対して正確な判断ができないことがわかる。

\section{2 電極幅 $30 \mu \mathrm{m}$ のスクリーン印刷実験}

次にさらに狭い電極形成を試み, 設計ライン幅 $30 \mu \mathrm{m}$ の スクリーンを使用し，それぞれのペーストの印刷特性を確認 した. 設計ライン幅以外の印刷条件, 評価方法は設計ライン 幅 $50 \mu \mathrm{m}$ と同じである。電極形状と外観形状の代表例を Table III および Fig. 10 に示す。また Fig. 11 にその電極の表 面粗さ結果を示す。設計ライン幅が $30 \mu \mathrm{m}$ に狭まると, 設 計ライン幅 $50 \mu \mathrm{m}$ で良好な電極形状であったペースト Uは 電極が上下に大きくうねった形状になり電極高さの標準偏差 が大きくなった。 ペースト $\mathrm{H}$ が電極の平均高さが最も高く, 標準偏差が小さく, 電極表面が平滑であり, アスペクト比も 大きく, 最も良好の電極形状となった. これらの傾向は, 上 述のデータからは説明することが困難であり, 電極幅が極端 に狭くなると異なった要因の検討が必要であることがわかる. 以後, 印刷結果がそれぞれで良好であるUと H の比較とし て議論を進める。

\section{3 メッシュを有するスクリーン開口部の通過性}

電極幅が $50 \mu \mathrm{m}$ では U が良好であったが電極幅 $30 \mu \mathrm{m} に$ なると $\mathrm{H}$ が良好となり，電極形状に大きな変化があること から, ペースト Uと H について電極幅 $30 \mu \mathrm{m}$ 印刷後のスク リーンマスクを観察した。版離れ後のスクリーンマスクの写 真の例を Fig. 12 に示す。また，スクリーンマスクの開口面 積に対して，版離れ後に開口部にペーストが残存している面 積からペースト残存率を求めた。結果を Fig. 13 に示す。電 極幅 $30 \mu \mathrm{m}$ の印刷の場合, ペースト Uはスクリーンマスク 側に残っていることが確認された。これは，スクリーンマス クへのペースト密着力が影響していることが考えられる。な お， $50 \mu \mathrm{m}$ の場合は，ペースト Uと Hで違いが見られな かった。

設計ライン幅が $50 \mu \mathrm{m}$ から $30 \mu \mathrm{m}$ に変更すると乳剤壁面 間隔が狭まるため, メッシュや乳剂壁面との摩擦，もしくは 付着の影響が大きくなり，そのため版離れ時にペーストが引 き上げられやすくなる。 U と H のワイヤーなどへの付着性 の違いが現れたものと予想される。また，曳糸性が高いペー スト Uは, 版離れのスクリーンマスクの移動とともにペー

Table III Electrode shapes obtained real screen printing processes with $30 \mu \mathrm{m}$ designed width.

\begin{tabular}{|c|c|c|c|c|}
\hline \multicolumn{2}{|c|}{ Silver paste } & $\mathrm{N}$ & $\mathrm{U}$ & $\mathrm{H}$ \\
\hline \multicolumn{2}{|c|}{ Electrode width $\mathrm{W}(\mu \mathrm{m})$} & 51.9 & 43.4 & 44.7 \\
\hline \multirow{3}{*}{$\begin{array}{l}\text { Electrode } \\
\text { thickness } \\
\quad(\mu \mathrm{m})\end{array}$} & maximum $\mathrm{H}_{\max }$ & 18.8 & 31.5 & 21.4 \\
\hline & minimum $\mathrm{H}_{\min }$ & 4.8 & 3.9 & 10.1 \\
\hline & average $\mathrm{H}_{\mathrm{ave}}$ & 11.4 & 15.0 & 15.8 \\
\hline \multicolumn{2}{|c|}{$\begin{array}{l}\text { Standard deviation of } \\
\text { electrode thickness (-) }\end{array}$} & 3.5 & 7.5 & 2.7 \\
\hline \multicolumn{2}{|c|}{ Aspect ratio $\left[\mathrm{H}_{\mathrm{ave}} / \mathrm{W}\right](-)$} & 0.22 & 0.35 & 0.35 \\
\hline \multirow{2}{*}{$\begin{array}{l}\text { Surface } \\
\text { roughness }\end{array}$} & $\mathrm{R}_{\mathrm{a}}(\mu \mathrm{m})$ & 2.5 & 4.9 & 2.0 \\
\hline & $\mathrm{R}_{\mathrm{z}}(\mu \mathrm{m})$ & 12.2 & 25.5 & 10.6 \\
\hline
\end{tabular}

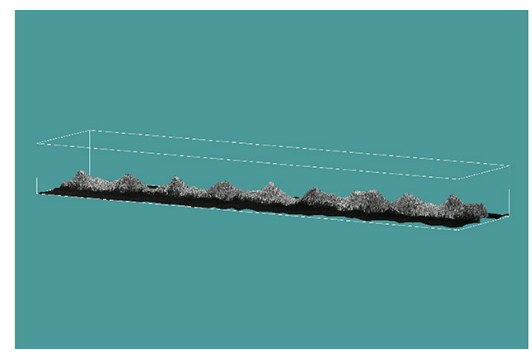

(A)

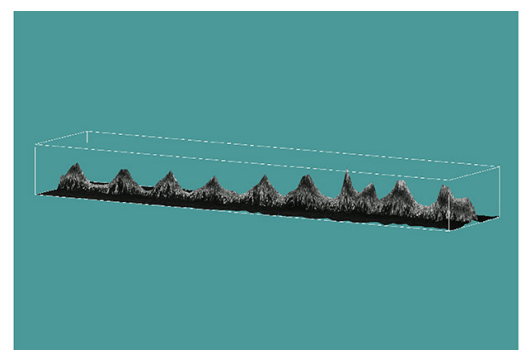

(B)

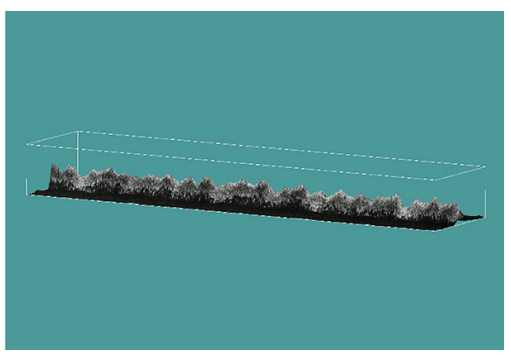

(C)

Fig. 10 Electrode shapes observed by confocal microscope obtained in real screen printing processes with $30 \mu \mathrm{m}$ designed width. (A) paste N, (B) paste U and (C) paste $\mathrm{H}$.

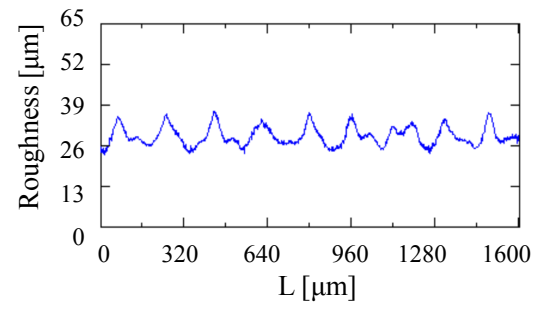

(A)

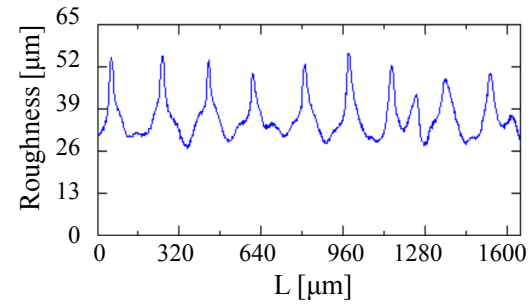

(B)

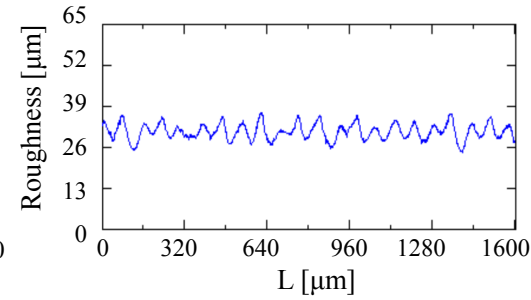

(C)

Fig. 11 Surface roughness of electrodes printed using $30 \mu \mathrm{m}$ designed width. (A) paste N, (B) paste $\mathrm{U}$ and (C) paste $\mathrm{H}$. 


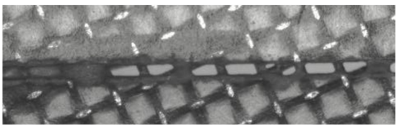

(A)

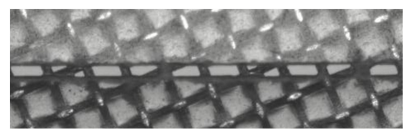

(B)
Fig. 12 Adhered pastes to mesh in screen masks of $30 \mu \mathrm{m}$ designed width after printing processes. (A) paste $\mathrm{U}$ and (B) paste $\mathrm{H}$.

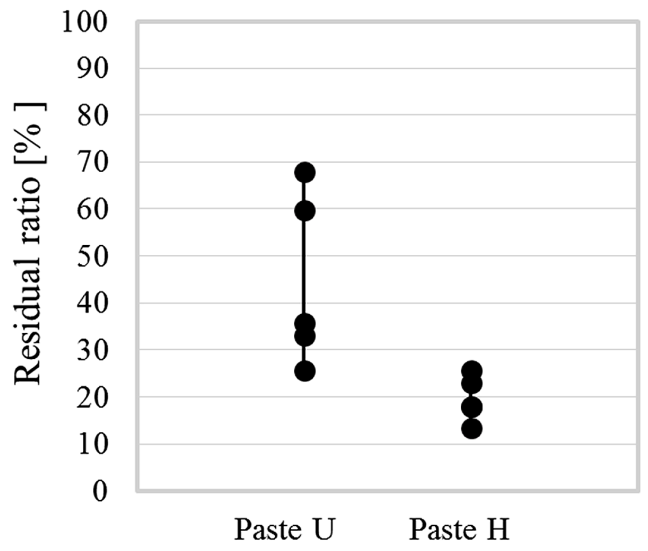

Fig. 13 Paste residual area ratio on screen mask of $30 \mu \mathrm{m}$ designed width after printing.

ストが引き上げられ，電極が大きくうねった形状になり，電 極高さの標準偏差や表面粗さも大きくなったと考えられる。

一方，かえって変形性が低いと判断されるペースト $\mathrm{H}$ は版 離れ時に, 素早くペーストが切れるため, 電極表面が結果的 に平滑となり，転写性が低下せず電極高さが維持されたとも 見なせる. 今後, 付着性などの検討を進める必要があるが, 極端に開口幅が狭いケースでは，さらに異なる観点からの印 刷性の検討が必要であることが分かったことは, 興味深い結 果と言える.

\section{5. 結言}

銀粒子の表面処理を変えたペーストを用い, そのレオロ ジー物性の評価と, スクリーン印刷工程の版離れ工程につい て, モデル化した流れ場で検討と微細線印刷を行い, 以下の 点を明らかにした。

バルクでのせん断特性として測定される物性は, 印刷性に 直接対応せず, 吸油量などの表面流動に影響する要因を検討 することが必要である。
電極幅 $50 \mu \mathrm{m}$ のスクリーン印刷では, 銀粒子の吸油量が 小さく銀粒子が完全に溶剤で浸漬される表面処理剤を用いる ことで, ペーストに流動性を与えスクリーンマスクから吐出 されやすく，電極形状が良好になることが確認された，電極 幅 $30 \mu \mathrm{m}$ になると乳剂壁面間隔が狭まる影響が生じ，異な る観点での検討が必要であることが確認された。

本研究では，スクリーン印刷における版離れ工程での基礎 的デー夕を得ており，今後これらを基に，印刷技術の向上に 関する研究がさらに展開されることが期待される。

\section{謝 辞}

実験にご協力頂いた新潟大学工学部流体工学研究室の若杉 昭行氏，小倉祐樹氏他の皆様，銀ペーストのご提供および印 刷および解析してくださいましたナミックス株式会社に感謝 の意を表します。

\section{REFERENCES}

1) de Vicente J, “Rheology”, (2012), InTech, Rijeka.

2) Frisson L, Lauwers P, Mertens R, Overstraeten RV, Govaerts R, Electrocomponent Science and Technology, 7, 107, (1980).

3) Thibert S, Jourdan J, Bechevet B, Chaussy D, Bruas R, Beneventi D, Materials Science in Semiconductor Processing, 27, 790, (2014).

4) Hoeniga R, Duerrschnabelb M, Mierloc W, Aabdinb Z, Bernhardc J, Biskupekc J, Eiblb O, Kaiserc U, Wilded J, Clementa F, Biroa D, Energy Procedia, 43, 27, (2013).

5) Masuri K, Function \& Materials, 30, 39, (2010), (in Japanese).

6) Hannebauer H, Falcon T, Hesse R, Dullweber T, Brendel R, Proc. 26th European Photovoltaic Solar Energy Conference and Exhibition, 1607, (2011).

7) Oonishi K, ToryounoKenkyuu (Kansai Kagaku, Jpn), 145, 6064, (2006) (in Japanese).

8) Hoornstra J, Weeber AW, Moor HHC, Sinke WC, ECN Solar Energy Report, ECN-RX-97-026, (1997).

9) Lin HW, Chang CP, Hwu WH, Ger MD, Journal of Materials Processing Technology, 197, 284, (2008).

10) Phair JW, Kaiser AF-J, Annual Transactions of the Nordic Rheology Society, 17, (2009).

11) Tubaki J, Suzuki M, Kanda Y, "Nyuumon Ryuusi Funtaikougaku”, (2002), Nikkan Kougyou Sinbunsya, Tokyo, (in Japanese). 